\title{
THE NEW TECHNOLOGY AND PURPOSES OF PADDY RICE PRODUCTION IN THE UPLAND OF SOUTH SULAWESI
}

\author{
Muhammad Agung Ady Mangilep ${ }^{1}$ \\ ${ }^{1}$ Faculty of Economics and Business, Hasanuddin University Makassar, \\ mycezar@gmail.com
}

\begin{abstract}
This research is aimed to investigate a relationship between the new technology and a continuation of paddy rice production in the upland of South Sulawesi. This research uses qualitative data obtained from a series of interview with farmers in the upland of South Sulawesi. Several new technologies can be adopted on paddy rice productions. Farmers select some technologies that match the farmers' purpose on their agricultural productions.
\end{abstract}

Keywords: paddy rice production, farmer behaviors

\section{Introduction}

This research purpose is to find out a relationship between the new technology and a continuation of paddy rice production in the upland of South Sulawesi. It is found that farmers adopt some of the new technologies on paddy rice production based on their purposes on agricultural productions.

Paddy rice production has an important role in a daily life of people in South Sulawesi and Indonesia as the most important main food. As the population grows, the demand for rice is increasing and maintaining a sufficient supply of rice becomes an important policy for central and local governments. To increase paddy rice productivity, government and agricultural scientist believe that an adoption of new technologies should be implemented. Research institution and universities had introduced some technologies including many new rice varieties. However, some researchers point out that farmers are reluctant to adopt new technologies.

It looks like farmers prefer to keep their current technologies rather than accepting new technologies. For a research question, are new technologies relevant to farmers' purposes on paddy rice production? My hypothesis is although there are new technologies available they are not relevant to farmers' purposes on paddy rice production. In this research, I use descriptive data of this research which were collected by field studies. Field studies were conducted by me to interview South Sulawesi farmers. The data are recorded on my notes and a voice recorder on interviews with farmers. Enrekang Regency, North Toraja Regency, and Tana Toraja Regency were chosen since they are located in the mountainous areas and farmer conduct paddy rice production. 


\section{New Technologies and Paddy Rice Production in Upland Areas}

Rice is the most important main food in Indonesia and Indonesia is among the largest group of rice consumers' countries. In Indonesia, paddy rice production is an important issue for the Indonesian government and some of the government policies are made for improving paddy rice production. The Indonesian Ministry of Agriculture (2014) has predicted that Indonesia will produce almost 70 million tons of paddy rice in 2014. The production is below that in 2013 which reached over 71 million tons. In South Sulawesi, paddy rice production contributes to rice production in Indonesia. Data from Indonesia's Central Bureau of Statistics (2014) shows that production of paddy rice in South Sulawesi increased from 3.4 million tons in 2005 to 5.4 million tons in 2014. So paddy rice production has increased 160 percent over 10 years. However, the growth tends to fluctuate.

Mangilep (2015) investigates some technologies developed for improving the productivity of paddy rice production. Those technologies were developed by Indonesian and international institutions. In this paper, I describe those technologies with their advantages for upland farming. The Genetic Evaluation and Utilization, supported by International Rice Research Institute (IRRI) as explained in Brady, etc. (1975). This technique can create improved paddy rice varieties by making a selection on paddy rice genes for a breeding. Biologists can choose those genes whose fit with a specific purpose such as varieties that resist to pests or diseases. Most of the agricultural lands in upland are rainfed which depend on a rainy season. This technology can be used to create adaptive varieties for rainfed areas but have high grain productivity. Those kind varieties may help upland farmers to increase their paddy rice productions and an implementation of those productions may increase the income of upland farmers.

The weeds control, supported by Australian Center for International Agricultural Research (ACIAR) as explained in Adiningsih, Semali, Effendi, and Hadiwigeno (1991). Weeds can grow everywhere. They absorb nutrients from the soil and they become a competitor for almost all plants. So that farmers have to eliminate weeds from paddy rice fields. A weeds control can be held by using herbicides which can be applied by spraying herbicide directly to weeds or by dissolving it into the water. A weeds control also can be applied by using organisms such as arthropods and fungus. Both arthropods and fungus are effective predators for weeds. A weeds control can assure enough amounts of nutrients that can be absorbed by paddy rice. Those nutrients will contribute to productive rice grain. They also may contribute to a better rice taste. Many people would like to eat a good taste paddy rice despite its price is higher than others.

Soil fertility management, supported by ACIAR as explained in Adiningsih, Semali, Effendi, and Hadiwigeno (1991). This method is a combination of agricultural practices based on an agricultural land condition in order to implement an efficient use of nutrients and water for a higher harvest. There some techniques for this method such as the use of an improved germplasm, agroforestry, crop rotation or inter-cropping. A germplasm can be modified to be more adaptive to a phosphate contained soil since upland agricultural lands are affected by this problem. 
Agroforestry using some trees such as leguminous trees and "Tithonia Diversifolia" are effective for supplying nitrogen into the soil. A crop rotation is a series of crop cultivations which one crop can only be grown in one or two years and then the crop replaces with another crop. This way can effectively conserve soil nutrients which maintain a balance proportion of nitrogen, phosphate, and potassium (NPK). By this method, farmers can maintain an environment of their agricultural production.

Soil conservation and erosion control, supported by ACIAR as explained in Adiningsih, Semali, Effendi, and Hadiwigeno (1991). In the upland areas, floods can happen in the rainy season. A flood may destruct the growing paddy rice and paddy rice fields. In an extreme case, a flood may trigger a landslide and broken down embankments of paddy rice fields. In a moderate case, an overflow of water on a paddy rice field can scrape a fertile layer away from the soil surface. So that erosion must be overcome to protect soil on paddy rice fields at upland. Erosion at upland can be controlled mainly by practicing terrace fields or contour fields. For upland's paddy rice fields, terrace or contour fields has been practiced in the mountainous areas in Indonesia since a long period of time. However erosions still happened, so that other techniques are needed to support the terrace or contour fields such as notillage farming, buffering stream banks, reducing waterproof surfaces and a forest conservation. Without tillage, crops on a rice field are remained untouched from the end of harvest time to the beginning of plowing. This method can prevent soil from water and wind exposures. Buffering a stream bank may prevent paddy rice fields from floods and erosion by growing some plants on the surface of a stream bank. Grasses, shrubs, and trees are useful for that purpose. Reducing waterproof surfaces may help to slow down water flow out from the paddy rice fields. Opened surface such on the paddy rice bank can be cultivated with plants such as grasses, shrubs and small trees. Those plants may help slow down the stream. Forest conservation may be able to prevent flooding and erosion on the agricultural land in upland. A dense forest provides an effective barrier for water flows since roots and plants covered soil can absorb water. Excessive water flows can be reduced by this method. The method is useful for maintaining upland agricultural infrastructures.

The integrated farming system, supported by ACIAR as explained in Adiningsih, Semali, Effendi, and Hadiwigeno (1991). This system is aimed to produce high standard organic feed, fibers, and renewable energy without polluted waste by using water, air, and nature in a sustainable circumstance. In the upland areas, a paddy rice production can be combined with a fish production and cattle's or poultry. Some paddy rice fields are wet fields in the upland so fish can lives there. Cattles or poultry produce wastes that can be used for fertilizers and biomasses. Paddy rice can be used for chicken feed and paddy rice straws can be used for cattle's feed. Those methods may be useful to increase farmers' income.

The System of Rice Intensification (SRI), supported by IRRI as explained in Rajendran and Daksinamoorthy (2005). This system was developed in Madagascar then spread throughout the world. The SRI is aimed to increase paddy rice productivity by using young seedlings. A young seedling is effectively less-resistant to environmental stress which helps it to produce more grains. For this method, young seedlings must be transplanted in a single form that contains two leaves. Water requirement for this technique is less than others because when paddy rice has started to grow, water in the paddy rice field will be dried. With a normal 
production, farmers can only harvest 2 tons per hectare. By using the SRI, farmers can produce about 8 tons per hectare. With a higher production, a farmer can raise his income.

Integrated crop management, supported by IRRI as explained in Rajendran and Daksinamoorthy (2005). This system is a dynamic system which promotes a sustainable farming by implementing a crops rotation, crop nutrition, soil management, seed and planting material, pest management, water management, site selection and landscape management in order to meet the local conditions and climate. A crops rotation is applied by growing some crops in a sequence such as cereals and legumes. This method can help farmers to improve soil nutrients and to reduce weeds, pests, and diseases. Crop nutrition may be reduced during farming with a crop. To restore soil nutrients, another crop such as legumes may help to increase soil nutrients again. Soil management is applied by reducing the use of chemical fertilizers. Chemical fertilizers can be replaced with animal wastes. This method may help farmers to maintain agricultural land naturally and to reduce production costs. For seed and planting material, improved varieties should be used and planting should adopt a condition of a paddy rice field. A transplanting method may be needed for an irrigated paddy rice field. A direct seeding method may be the best for paddy rice fields in upland areas which more rainfed than the lowland one.

Pest management gives a priority to a preventive action rather than a reactive one. Preventive action can be done by keeping a paddy rice field to be sanitized. A frequent observation should be done by farmers. Chemical herbicide and pesticide may be used for a preventive action but a careful application under its prescription should be done. A water management for paddy rice production should concern for an efficient use of water. In a rainfed paddy rice field in upland areas, typically water is needed in the period of planting. Then water can be reduced gradually. A site selection can be done by renting or buying a land which can be managed for a paddy rice production. Upland varieties typically have a drought tolerance so that they can grow at the less-irrigated fields and for that kind, land can be rented or bought. Farmers can increase productivity by conducting a combination of paddy rice production and other agricultural productions. For this purpose, a landscape management is needed to locate the best areas for a paddy rice production, a fish pond, a cattle pen, vegetable productions, plantations and so on.

Drone for agriculture, supported by Massachusetts Institute of Technology (http://www.technologyreview.com/featuredstory/526491/agricultural-drones). A drone is a mini flying machine that can be controlled by a radio transmitter tool. It can works on a wide area with different altitudes. Uplands are typically sloped areas which may prevent an implementation of agricultural machinery. Big roads may be rare and existed roads sometimes in a bad condition, so that big agricultural machinery cannot be used. A production in such slopes is also costly and timeconsuming. A drone may be useful to overcome that problem. A remote-controlled drone can be useful to distribute fertilizers, herbicides, and pesticides from the air.

However, most of those technologies have not been applied in the upland area of South Sulawesi so far. Weeds control, soil fertility management, soil conservation, erosion control, integrated farming system are also introduced by the government and foreign institutions, but farmers had stuck to their own way of production. The 
system of rice intensification and integrated crop management are also introduced by a foreign institution and are supported by the government, but farmers have been unwilling to implement them to their management strategy. A drone is developed by a foreign institution and is considered to be very useful in distributing fertilizers and pesticides effectively, but farmers lack information on pros and cons of using a drone.

There are many new varieties of paddy rice that have been invented, but only a few of them have been implemented. The Government of Indonesia with IRRI has sponsored many inventions of new rice varieties. Many institutions in Indonesia also supported invention of new varieties, such as universities and research centers. There were not many paddy rice varieties that had been launched before 1970 . According to Suprihatno and Daradjat (2009), the IRRI had launched the more modern varieties of paddy rice type at the end of 1960. In the period of 1970-1984, many types of paddy rice varieties were launched. After 1984, many types of paddy rice varieties, more than those in previous periods, were launched. One of them, the IR64, had become the most popular paddy rice variety in this period. The IR64 was developed in 1986 but then it became susceptible to bacterial leaf blight, and to green and brown leafhoppers. To overcome those problems, a research center in the Indonesian Ministry of Agriculture found several new paddy rice varieties were developed such as the Ciliwung (1989), the Way Seputih (1989), the Barumun (1991), the Memberamo (1995), the Way Apo Buru (1998), the Widas (1999), the Ciherang (2000), the Konawe (2001), and the Cigeulis (2003). From 2004 to 2008, The Indonesian Paddy Rice Research Centers released a lot of new types of paddy rice varieties such as the Ciherang, the Mekongga, and the Inpari series for irrigated lands, the Inpara series for swamp lands, and the Sarinah, the Situ Patenggang, the Situ Bagendit and the Ingogo series for uplands. Lestaria, Abdullah, Junaedib, and Aswidinnoorb (2011) explains that 49.4 percent of paddy rice fields use the Ciliwung variety in South Sulawesi. In the upland area, farmers use local varieties and there are some local varieties such as the Pulu Mandoti, the Pinjan, the Pare Bau and the Lambau which are treated as parents of the aroma gene source for New Plant Types (NPTs) of aromatic lines by the Bogor Institute of Agriculture (IPB).

Though many types of new varieties have been released, only a few of them are used widely. The decision for the adoption of a variable depends on the middlemen such as seed producers who do not like to produce unpopular types of rice seeds and rice mill companies who make disincentive for grains of unpopular rice types. Suprihatno and Daradjat (2009) claim that adoption of new varieties depends on five actors; farmers, seed producers, grain traders, rice mill owners, and consumers. Many researchers and public officers in agricultural extensions of the government have not concerned the role of the five agricultural actors.

\section{Farmers' Perspective on an Implementation of New Technologies on Paddy Rice Production in Upland Areas}

Farmers would increase paddy rice production by adopting new technologies. There are a lot of technologies available. However, it looks like that farmer reluctant to adopt new technologies. Soekartawi (1995) points out that farmers are reluctant to implement new technologies since the implementation of new technologies relates to risks of a stability of their farms. Farmers could increase their production by using 
new technologies. However, farmers must expend a cost of an installation of new technology and its operational costs. Farmers are not sure that their investments can make a higher profit than before the investments. Sjakir, etc. (2015) points out that farmers' knowledge and a government's agricultural agency can promote adoption of new technologies. Knowledge makes farmers understand the benefits from an implementation of the new technology. A government's agricultural agency has a complete information about new technologies and an access to farmer groups which can easily distribute information to their members. The government also can distribute agricultural subsidies to farmers.

Not all paddy rice productions have a commercial purpose that affects farmers adopting new technologies. Mangilep (2016) finds out that farmers in the upland of South Sulawesi produce paddy rice for a non-commercial purpose. Farmers in Enrekang Regency keep a paddy rice production as a part of a production system on a red onion production. Farmers can minimize pest problems by producing paddy rice between two consecutive red onion productions. Farmers in Tana Toraja Regency and North Toraja Regency keep a paddy rice production in order to maintain values of their big families' assets. Paddy rice production is a part of the Torajans' life values which are symbolic presented as a complex of a "Tongkonan", a traditional paddy rice storage, with paddy rice fields.

In fact, those papers did not address the implementation of new technologies on paddy rice production. From the results of interviews with farmers in Enrekang Regency and Torajans regencies, I find some implementation of new technologies. Farmers in Enrekang Regency and North Toraja Regency produce paddy rice production combined with a fish production and cattle or poultry. This practice is a part of the integrated farming system where farmers can make incomes from the sale of fish, cattle, and poultry. An integrated crop management by rotating production of red onion and paddy rice is practiced by farmers in Enrekang Regency. The SRI is practiced by farmers in Enrekang regency. The genetic evaluation and utilization are practiced by farmers in Enrekang Regency and Torajans regencies who use both government and local varieties in order to keep good harvests.

There are some reasons for the implementation of new technologies by farmers in the upland of South Sulawesi. Farmers receive subsidies by using government distributed fertilizers for paddy rice production. By applying this strategy, farmers could reduce a cost of production. By reducing a production cost, farmers could manage their profit and by this way, they could maintain the continuity of their profits.

Popular government paddy rice varieties used by upland farmers were not developed for upland paddy rice production. However, farmers use those varieties intermittently with local paddy rice varieties. Government paddy rice varieties are typically high productivity but most of them have a lower quality than local upland varieties. Local upland varieties are high quality but their productivity is low. By using government varieties, farmers can maintain their rice stocks and farmers can sell or use their surplus for their daily and other needs. A production of government paddy rice variety is supplied with government distributed fertilizers, so that farmers can use the subsidized fertilizers for their own purpose.

Accessibility can influence farmers' decisions to adopt new technologies. Rural 
infrastructures, such as roads, are limited and they cannot be used to deliver a large scale agricultural machine and this action could cost farmers a lot of money. So that chimerization cannot be applied in farmers' strategies to increase their productivities. Machines also cost farmers some utilities such as gasoline and lubricants. Machines also have a handicap if they are used on terrace fields which cost farmers to use special vehicles in order to move machines from one terrace field to others.

\section{Conclusion}

Farmers in the upland of South Sulawesi apply some technologies that could keep their strategy to increase and to maintain incomes from farming. Incomes from farming come from some agricultural activities and a paddy rice production is only one of them. Farmers select new technologies that enable them to receive subsidies, to ensure their rice stocks and to cope with the constraints of the ground surface on their paddy rice fields.

Chimerization is not an effective way to increase their productivity. Using a large agricultural machine could generate some costs that affect farmers' profit and could disturb the continuity of their agricultural productions. That disturbance could increase the farming risk for farmers.

\section{REFERENCES}

Adiningsih, Semali, Efendi, Hadiwigeno (1991) ACIAR: Technologies for Sustainable Agriculture on Marginal Uplands in Southeast Asia. Retrieved from http://aciar.gov.au/publication/pr033

Brady, N. C., Athwal, D. S. (1975) Future Emphasis on Upland Rice. IRRI: Major Research in Upland Rice. Retrieved from http://books.google.co.jp/books?id=8PXmRSBvlOgC\&printsec=frontcover\&hl= id\&source=gbs_ge_summary_r\&cad $=0 \# v=$ onepage $\& q \& f=f a l s e$

Indonesian Ministry of Agriculture (2014) Data Terkini Subsektor Tanaman Pangan. Retrieved from http://www.pertanian.go.id/Indikator/tabel-1-prod-Ispnproduktivitas-padi-palawija.pdf

Indonesia's Central Bureau of Statistics (2014) Statistik Tanaman Pangan. Retrieved from http://www.bps.go.id/tnmn_pgn.php

Lestaria, A. P., Abdullah, B., Junaedib, A., Aswidinnoorb, H. (2011) Performance of Grain Quality and Aroma of Aromatic New Plant Type Promising Rice Lines. Retrieved from http://pustaka.litbang.deptan.go.id/publikasi/as122115.pdf

Mangilep M. A. A. (2015) Socioeconomic Problems on Adoption of New Technologies for Production of Paddy Rice by Farmers in Upland Areas of South Sulawesi. Studies in Humanities and Social Study of Chiba University, Vol. 30 - 2015.9. Chiba University.

Mangilep M. A. A. (2016) the Importance of Paddy Rice Production for the Agricultural Communities in the Highland of South Sulawesi. The 7th Indonesia Japan Joint Scientific Symposium. Chiba University. 
Rajendran, R., Daksinamoorthy, M. (2005) Innovative Production Technologies for Maximizing Rice Productivity and Profit. Retrieved from http://www.slideshare.net/mdmoorthy/innovative-production technologies-formaximizing-rice-productivity-and-profit

Sjakir, M., Awang, A. H., Manaf, A. A., Hussain, M. A, Ramli Z. (2015) Learning and Technology Adoption Impacts on Farmer's Productivity. Mediterranean Journal of Social Sciences Vol 6 No 4 S3 August 2015, ISSN 2039-2117 (online). MCSER Publishing, Rome-Italy. Doi:10.5901/mjss.2015.v6n4s3p126

Soekartawi. (1995). The farming analysis in Indonesia. Jakarta: UI-Press.

Suprihatno B., Daradjat A. A. (2009) Kemajuan dan Ketersediaan Varietas Unggul Padi. Publikasi Balai Besar Penelitian Tanaman Padi. Retrieved from http://www.litbang.deptan.go.id/special/padi/bbpadi_2009_itkp_12.pdf 